\section{Bangladesh reviews science policy}

MODERn science and technology was introduced to the Indian sub-continent by the British during the late 19th century. It developed in only a few areas of present day India, no significant development taking place in those areas which now make up Bangladesh and Pakistan. A national policy for science and technology development there was initiated as late as the 1960s. Planning and executive agencies were subsequently formed and some institutions for scientific and technological education and for research and development were established. Over the last ten to fifteen years an indigenous scientific and technological infra-structure has begun to be built up in Bangladesh.

The need for an integrated science and technology policy in Bangladesh has led to the formation of the National Council for Science and Technology (NCST) to advise the government on formulating policy, and planning, coordinating and evaluating science and technology development. In concrete terms the NCST determines national objectives, formulates strategy and identifies areas where science and technology can contribute to national development. The talks also include coordinating and evaluating scientific and technological programmes in various sectors, and the development and motivation of scientific and technical manpower.

The government of Bangladesh has now undertaken economic development programmes to raise the standard of living of the people and improve socio-economic conditions. Implementation of these programmes needs specific technological capabilities. Any assessment of future possibilities and formulation of appropriate development strategies must be based on an analysis of national strength and weaknesses which should take into account the potential contribution that science and technology can offer. Science and technology policy for both short and long term strategies, thus, constitutes an integral part of the country's overall development plan.

With a view to planning and programming scientific and technological developments effectively, the NCST has undertaken to establish a data base on manpower, and the funding, management and facilities for the existing scientific and technological infrastructure. This would involve surveying existing scientific and technological personnel and stock taking of the research institutes, laboratories, workshops and supporting facilities. The current programmes in these institu- tions are to be reviewed and plans for the development of existing scientific and technological institutions are to be made on the basis of the results of these surveys and reviews. Further, NCST intends to undertake studies and make recommendations on the organisation and modes of financing of the research councils, institutes and other supporting facilities.

On the development of human resources in science and technology in Bangladesh, NCST proposes to review the existing education and training programme and suggests appropriate measures for their expansion and improvement. Recruitment and promotion rules for scientific and technical personnel with appropriate measures for proper incentive and motivation. The government has already instituted a fellowship programme for science, engineering, medical and agricultural graduates who cannot find suitable employment inside the country or experts working abroad but interested

in joining the institutions of Bangladesh.

NCST intends to undertake a comprehensive scheme for preparation and production of science and technology text books in Bengali and reference books in both Bengali and English up to the highest level of education and to advise the government on its phased implementation. Popularising science and technology and disseminating scientific knowledge among the public, particularly on the human implications and social impacts of science and technology will be one aim. In the long term these studies should lead the government and other concerned agencies to formulate the philosophy, guidelines and workplan for a course of action.

Bangladeshi science and technology policy also envisages longterm studies on the development of scientific and technological potential, appropriate or alternate technologies, policy guidelines for international and regional cooperation and promotion of associations, academic and professional bodies and human rights for scientists.

M. Kabir

\title{
FAO conference embraces third world
}

WHEN, in January 1976, Edouard Saouma, a Lebanese Christian, took over as Director General of the Food and Agriculture Organisation (FAO), there was a good deal of headshaking among the old hands in international agriculture, and when he announced his policy for improving the efficacy of the organisation, there was even more heart-searching among the senior staff. His policy was aimed specifically at more direct contact with ministries of agriculture and development in the Third World countries.

The FAO biennial Conference, which ended early in December at the headquarters in Rome, must have given Saouma a good deal of satisfaction. After two years of his regime, government after government expressed approval and encouragement for the policy at which many of their representatives had looked askance early in 1976. Nor did this approval come only from the Third World countries towards whom the new policy has been especially directed.

The most far-reaching of Saouma's ideas has been the Technical Cooperation Programme. Seen initially by many as a duplication of effort with the UN Development Programme (UNDP) this has now proved its ability to provide small-scale assistance for specific projects at very short notice-something the cumbrous machinery of UNDP has never been able to provide. In its first year, 190 projects have been approved under this programme. The success of this scheme certainly owes a good deal to another innovation, much criticised when announced: the appointment of FAO representatives to certain countries, again in order to provide direct and rapid contact in critical areas.

Two other activities came in for special approval from many delegates in Rome. One was the Seed Improvement and Development Programme, fundamental to increased production in the developing countries. The other is the campaign against post-harvest food losses-something for which every FAO Conference has asked since the organisation came into being. Since it is estimated that cutting such losses by half could save up to $\$ 7,500$ million a year in the foreign exchange for the developing countries, the amount allotted for initiating this campaign, a mere $\$ 10,000$, seems modest indeed. It is hoped to double this with external contributions.

Referring to the 1979 World Conference on Agrarian Reform and Rural Development, Saouma said that he wishes to "avoid confrontation, rhetoric and confusion"; many observers must have noted that he certainly managed this at his own Conference, at a time when politicising and backbiting have come to be a normal part of such major international meetings. This is perhaps another good augury for his ability to control the spending of the $\$ 237,377,000$ he is asking for his regular budget for the biennium 1978-79.
Peter Collins 